\title{
調查報告
}

\section{ナイルデルタ流域に扫ける集落排水処理施設の 構築とその運転状況}

\author{
小木曽 凡芳 ${ }^{* * *}$, 大石 貴行 **, 鈴木 祥広 ${ }^{* * *}$
}

\section{要旨}

本調査報告では, 新興国共通の課題として挙げられる農村部に適した低コスト型, 維持管理簡易型の下 水道処理施設の開発を目的とし, ナイルデル夕地域において集落排水処理施設を設置し, その運転状況を 調査した。流入水と放流水の各水質項目で評価した結果, BOD $88 \%, \mathrm{COD}_{\mathrm{Cr}} 82 \%$, 濁度 $81 \%$ ，大腸菌群数 $99 \%$ の除去率が得られた。建設費は，500人の計画人口に対し，総工事費 $\$ 76,000, \$ 152 /$ 人となっ.

キーワード：集落排水処理施設, ナイルデルタ, 新興国, 低コスト型, 維持管理簡易型

\section{1.はじめに}

エジプト国では，急激な人口増加（年 $2 \%$, 約 150 万人/年) に伴い, 水の消費量が増大している。さら に, 食料増産のための農地開発及び経済成長も加わり, 農業・工業・生活用水の水需要が大幅に増加してい る.エジプト国は，この水使用の $80 \%$ 以上をナイル川 に依存している。また, 使用後の水も全て最終的にナ イル川へ排水されており, ナイル川下流域の水質污染 は深刻な状態となっている ${ }^{1-4)}$. 水質污濁の原因は, 農地開発, 経済成長にも起因しているが5), 下水道整 備率の低さが大きな要因となっている。エジプト国内 の下水道整備率は，2011年において，都市部90\%，農 村部 $12 \%$, 全体の平均として $50 \%$ との報告がある ${ }^{6)}$. 実際に現地で調査したところ, 維持管理が十分に成さ れておらず，運転を停止している施設，十分に処理さ れていない施設が数多く見受けられ，下水道整備率に 含まれる処理施設も完全に機能を発揮している状態で はない. また，農村部の下水道整備率は，12\%とされ ているが，実際には腐敗槽などの簡易処理も含まれて おり, 適切に 2 次処理まで行われている施設は数力所
である。

エジプト国の 1 人当り名目 GDP は, 2004年に $\$ 1,137$ であったものが，2014年には， $\$ 3,303$ となり，10年間 で2.9倍に上昇している。 人口も, 年間約 $2.0 \%$ の増加 率となっており，近年急成長している国である。エジ プト国のように経済成長が著しい新興国においては, 人口の増加や産業の発展により, 水質污染, 土壤污染, 大気污染など多くの共通課題を有している。また, 多 くの新興国では, エジプト国と同様に下水道整備率が 低く, 技術レベルも高くなく, 技術者も不足している. このような背景において, 新興国への低コストで容易 な維持管理を実現可能な下水処理施設の導入が急務と なっており，エジプト国内でも他型式での施設建設及 び研究が行われている. 上村ら ${ }^{7)}$ は, 「初沈 +DHS (下 降流スポンジ懸垂リアクター)」を設置, 進藤ら ${ }^{8)}$ は, 「嫌気槽，ばっ気槽，植生浄化槽を組み合わせた方式」 による施設を建設した。ナイルデルタにある農村部の 水不足と水質污濁を解消し, 農業排水の灌溉利用を促 進することを目的として, 現地においてパイロット式 の集落排水処理施設を設置した. このプロジェクトの 主要な目的は集落排水の処理であり, 日本で多く実績

2016年 2 月16日受付, 2016年 6 月 3 日受理

Construction and Operating Conditions of Rural Sewage Treatment Facility in Nile Delta

*宮崎大学大学院農学工学総合研究科 OGISO Tsuneyoshi

**(株)三祐コンサルタンツ OISHI Takayuki

***宮崎大学工学部社会環境システム工学科 SUZUKI Yoshihiro 
のある集落排水処理施設をさらに簡易化し, 現地に実 験施設を建設した。そその運転状況及び今後の展開につ いて報告する。

\section{2. 集落排水処理施設の概要}

\section{1 プロジェクトの概要}

図 1 に, パイロットプロジェクトの概念図を示す. パイロットプロジェクトは, 農業排水を再利用するた め，下記の施策を総合的に実施した。

(1)環境教育

(2)集落排水処理施設建設

(3)水路内浄化施設建設

(4)コンポスト施設建設

(5)再利用ポンプ建設

(6)組織強化

パイロットプロジェクトは, 集落排水処理施設とコ ンポスト施設によって, 污濁負荷を軽減し, すでに污 濁の進んだ排水路の直接浄化施設により排水路水質を
向上し, 再利用ポンプにより排水路から, 灌溉水路一 の揚水を行うという一連のパッケージである.ささに 環境教育と組織強化のソフト施策により, プロジェク トの継続性を図ったものである。そのパッケージのコ アとなる施設が集落排水処理施設である.

\section{2 集落排水処理施設の概要}

集落排水処理施設は, 図 2 に示すエジプト国北部の サンデラ村に設置した. サンデラ村は, 北緯 $31.16^{\circ}$, 東 経 $30.81^{\circ}$, 地中海まで約 $40 \mathrm{~km}$ の地点に位置する. 現 況人口は 286 人, 全家屋69軒の小さな農村である. 施 設の概要をとりまとめれば，以下のとおりである.

(1)計画年次；2033年（20年後）

(2)計画人口； 500 人

(3)日平均污水量原単位; $70 \mathrm{~L} /$ 人 ·日

(4)日平均污水量 ; $35 \mathrm{~m}^{3} /$ 日

(5)計画流入水質 ; BOD $360 \mathrm{mg} / \mathrm{L}$

(6)計画放流水質 ; BOD $60 \mathrm{mg} / \mathrm{L}$

処理方式は, (一社) 地域環境資源センター（JARUS）

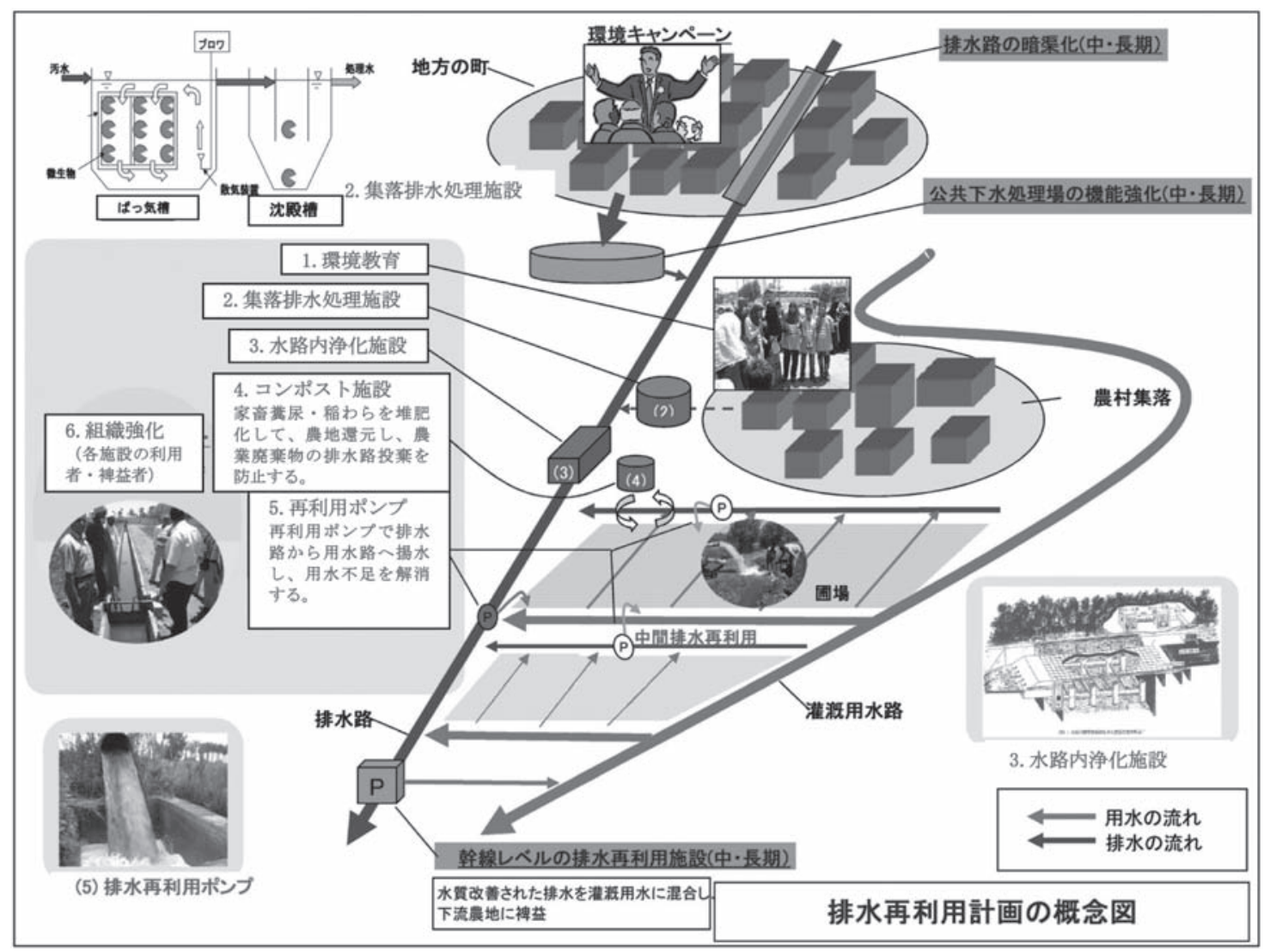

図 1 プロジェクト概念図 




図 2 施設位置図

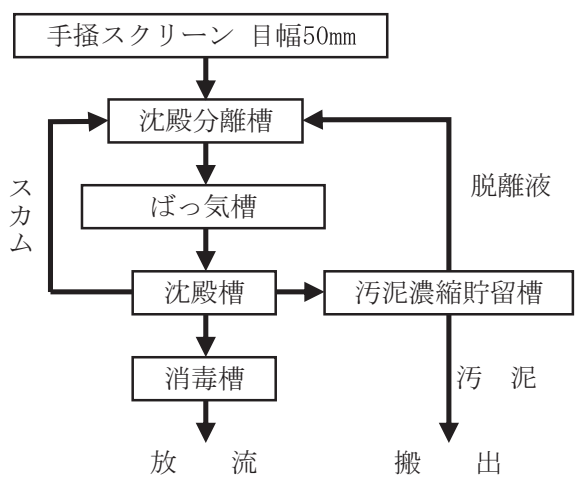

図 3 施設フローシート

I 型と称される「沈殿分離及び接触ばっ気を組み合わ せた方式」を基本とした．図 3 に集落排水処理施設の 処理フロー, 図 4 に施設構造図を示す。また, 写真 1 に施設の全景を示す。

施設は全長 $22.35 \mathrm{~m}$ ，幅 $3.00 \mathrm{~m}$ ，深さ $3.95 \mathrm{~m}$ であ り, 施設用地の確保を考慮し, 排水路の維持管理用道 路下に設置した，写真 1 に全景を示すが，建屋は，排 水路内への張り出し構造とし, 処理水槽は, 管理用道 路下とした，処理水槽は覆蓋することにより，臭気対 策とした，表 1 に，各放流水槽の寸法及び滞留時間を 示す。施設全体の計画滞留時間は, 54.1時間である。 施設構造は, 日本農業集落排水協会一I 96型設計指針 に準拠して計画した。

日平均污水量原単位は, 給水量より決定した。 エジ プト国の平均的な給水量として, カイロ（人口800万
人）等の大都市で $300 \mathrm{~L} /$ 人・日，シャルキア（人口 30 万人) 等中都市で $143 \mathrm{~L} /$ 人 ・ 日，ミニア (人口 25 万人) 等の地方都市で $70 \mathrm{~L} /$ 人・日としている.このことか ら, サンデラ村は, 農村部であり, 給水状況も良くな いため地方都市の $70 \mathrm{~L} /$ 人・日として計画した。

ばっ気槽は, BOD 負荷 $0.3 \mathrm{~kg} / \mathrm{m}^{3}$ ・日以下となる容 量を確保し, ブロワー能力を $2.0 \mathrm{~m}^{3} / \mathrm{m}^{3}$ ・時以上とな るように設定した。 その結果, $2.2 \mathrm{kw}$ のブロワーを 常用 1 台, 予備 1 台として設置した.

\section{3 コスト縮減対策}

対象となるサンデラ村は, ほとんどの住民が農畜産 業にて生計を立てており, 経済的にも裕福ではなく, 集落排水処理施設を管理できる技術者もいない. した がって, 維持管理が容易で安価となる施設とする必要 がある。また，これをモデル地区として，エジプト全 国及び他の新興国に展開するために建設費も縮減する 必要がある。

\subsection{1 建設費の縮減}

建設費の縮減対策としては，以下の施策を図った。

(1)ばっ気槽に投入する担体として, 現地で安価に入手 可能な電線管を利用した。担体は, 写真 2 に示すビニ ル製電線管 $\phi 25 \mathrm{~mm}$ を $5 \mathrm{~cm}$ 程度に切断してばっ気槽へ投 入した. 比重は1.0以下であり, ばっ気によって槽内 の循環流とともに流動する。電線管は, 地方でも容易 に入手でき， $\$ 0.05 / \mathrm{m}$ であることから，担体 $1 \mathrm{~m}^{3}$ 当 たりのコストは $\$ 100$ 程度である。 また, 担体流動式に することにより, 生物膜法で重要となる生物膜の管理 


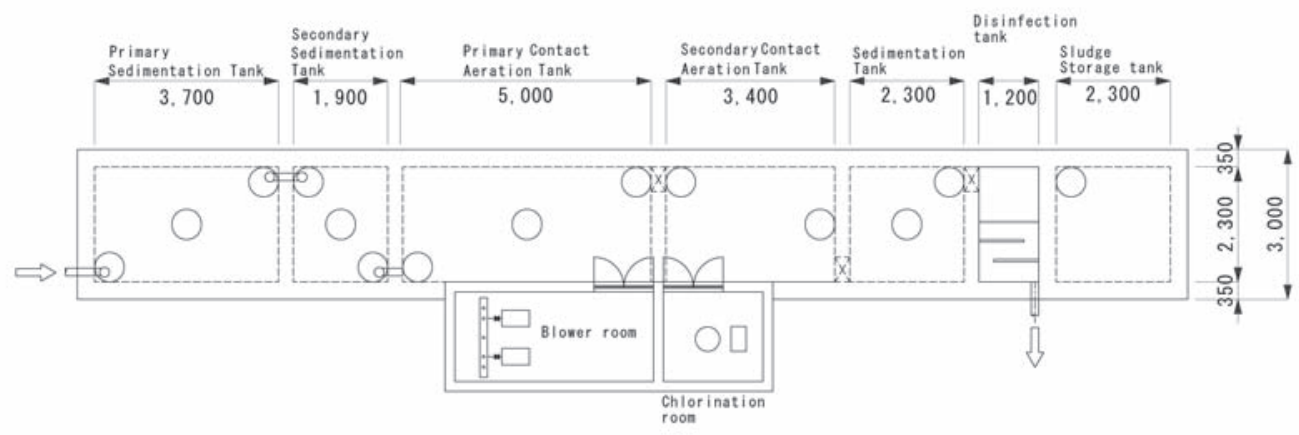

平面図

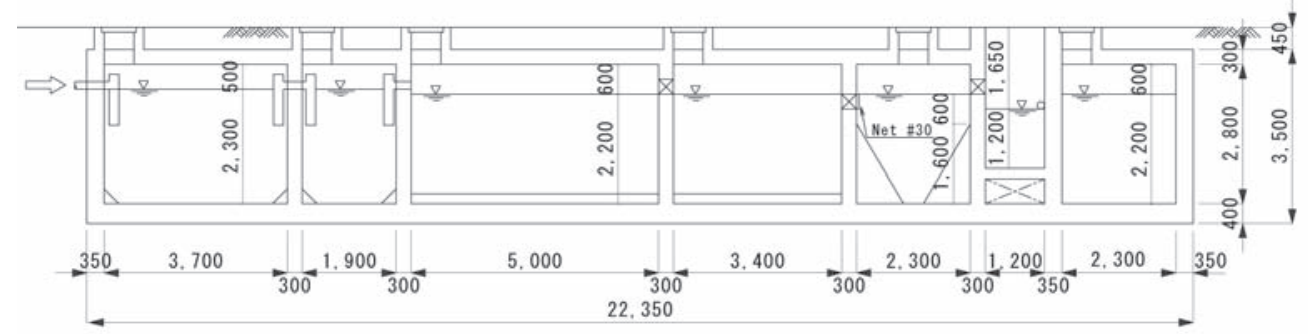

断面図

図 4 施設構造図

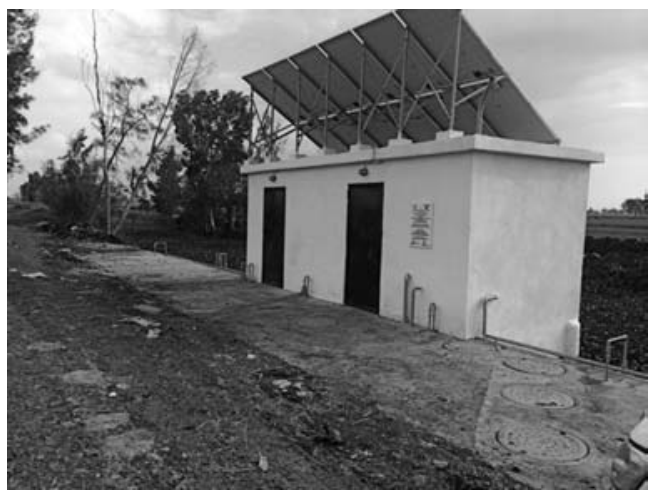

写真 1 集落排水処理施設全景

表 1 処理水槽寸法及び滞留時間

\begin{tabular}{l|c|c|c|c|c}
\hline \multicolumn{1}{c|}{ 槽名称 } & $\begin{array}{c}\text { 幅 } \\
(\mathrm{m})\end{array}$ & $\begin{array}{c}\text { 長さ } \\
(\mathrm{m})\end{array}$ & $\begin{array}{c}\text { 有効 } \\
\text { 水深 } \\
(\mathrm{m})\end{array}$ & $\begin{array}{c}\text { 有効 } \\
\text { 容量 } \\
\left(\mathrm{m}^{3}\right)\end{array}$ & $\begin{array}{c}\text { 滞留 } \\
\text { 時間 } \\
(\mathrm{hr})\end{array}$ \\
\hline 沈殿分離槽第 1 室 & 2.3 & 3.7 & 2.3 & 19.5 & 13.4 \\
\hline 沈殿分離槽第 2 室 & 2.3 & 1.9 & 2.3 & 10.0 & 6.8 \\
\hline ばっ気槽第 1 室 & 2.3 & 5.0 & 2.2 & 25.3 & 17.3 \\
\hline ばっ気槽第 2室 & 2.3 & 3.4 & 2.2 & 17.2 & 11.7 \\
\hline 沈殿槽 & 2.3 & 2.3 & 2.2 & 5.8 & 4.0 \\
\hline 消毒槽 & 1.2 & 1.2 & 1.0 & 1.4 & 0.9 \\
\hline 合 計 & - & - & - & 79.2 & 54.1 \\
\hline
\end{tabular}

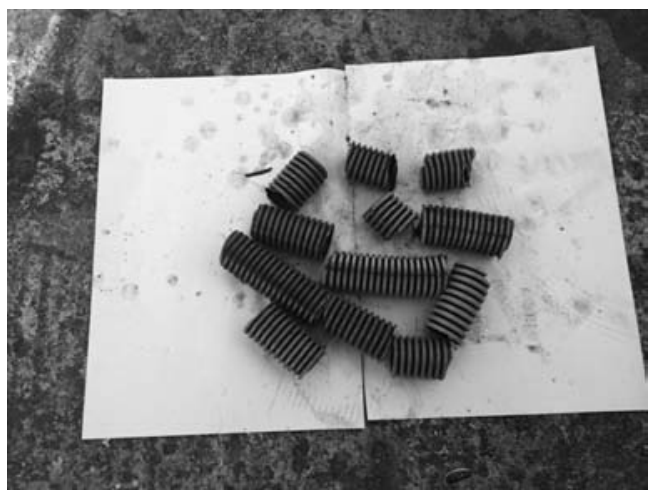

写真 2 ばっ気槽内担体

が不要となり，逆洗などの操作を省略できるように配 慮した。ただし，担体が劣化及び流出により減少した 場合には，追加投入が必要となる。

(2)ブロワー (イタリアROBUSCHI 社製)，スカムス キマー (エジプト製), 消毒器 (イタリア Etatron 社 製), 配管設備（エジプト MISR ELHEGAS 社製）等 現地で調達可能な資材は, エジプト国での普及品とし た。ただし, 処理性能に大きな影響を与える散気装置 (マルチフューザー）と空気流量計（日本フローセル FLT 型) は，日本製品を現地へ持ち込んだ.

(3)沈殿槽の越流堰を 1 辺のみのコンクリート製とした. 
以上の施策を含め, 現地の施工業者によ る施工としたことによって, 処理施設建 設費は, 太陽光発電設備を含め, $\$ 76,000$ となった。また，管路は， $\phi 150 \mathrm{~mm}$ の塩 ビ管を $530 \mathrm{~m}$ 敷設し, $\$ 19,500$ の事費 となり, 総工事費は, $\$ 95,500$ となった。 用地取得費用は, 施主である排水庁の土 地を利用したことから，工事費には含ん でいない.

\subsection{2 維持管理費の縮減}

維持管理費の縮減及び容易性の実現の ために以下の施策を図った。

(1)太陽光発電によって, 電気代の節約を 検討した. 集落排水処理施設運転に必要 な電力は, ブロワー $2.2 \mathrm{kw}$ と塩素注入 装置0. $05 \mathrm{kw}$ のみである. 日中 8 時間を 太陽光発電によって, $1.5 \mathrm{kw}$ を賄う計 画とした。

(2)日本国内では, 機器精度及び維持管理 技術も高度であることから, タイマー制 御等により維持管理を行うことが可能で あるが, 維持管理の確実性, 容易性を考 慮して, 全て手動バルブ操作のみで運転 することとした．

(3)污水は全て自然流下とし, 沈殿槽から 沈殿分離槽または污泥濃縮貯留槽への污泥移送と沈殿 槽からのスカム移送は，エアリフトポンプによって

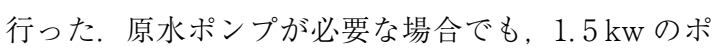
ンプを 2 台設置する程度であることから, 維持管理費 は年間 $\$ 50$ 程度増加するのみである。

\section{4 放流水質の調査}

本施設は, 2015年 7 月に運転を開始し, 機器の調整 を繰り返しながら，2015年10月に本格運転を始めた。 運転後, 10月27日と11月 3 日の 2 回にわたって, 水質 試験を実施した. 試料水は, 各層の水面下 $20 \mathrm{~cm} の$ 水を 洗浄済みポリエチレン瓶に採取し, 直ちに現地の実験 室 (Egyptian Public Authority for Drainage Project Central Department for East Delta Drainage project Central Department for Quality Assurance and control Soil and Water Laboratory）に持ち帰り，各項目の 水質分析を行った。表 $2 に$ に, 分析項目と分析方法を示 す.
表 2 分析項目亡分析方法

\begin{tabular}{|c|c|}
\hline 測定項目 & 測定法 \\
\hline 水 温 & ポータブル多項目水質計 WQC24 \\
\hline $\mathrm{pH}$ & $\begin{array}{l}\text { ポータブル多項目水質計 } \mathrm{WQC24} \\
\text { ガラス電極法 }\end{array}$ \\
\hline 濁度（TURB） & $\begin{array}{l}\text { ポータブル多項目水質計 WQC24 } \\
\text { 90度散乱光測定方式 (赤外光) }\end{array}$ \\
\hline 溶存酸素（DO） & $\begin{array}{l}\text { ポータブル多項目水質計 } \quad \mathrm{WQC} 24 \\
\text { ガルバニ式隔膜電極法 }\end{array}$ \\
\hline 残留塩素 & $\begin{array}{l}\text { デジタル残留塩素テスター HI711 } \\
\text { DPD 法 }\end{array}$ \\
\hline 亜硝酸態窒素 $\quad\left(\mathrm{NO}_{2}-\mathrm{N}\right)$ & $\begin{array}{l}\text { ポータブル簡易全窒素・全りん計 TNP-10 } \\
\text { ナフチルエチレンジアミン吸光光度法 }\end{array}$ \\
\hline 硝酸態窒素 $\left(\mathrm{NO}_{3}-\mathrm{N}\right)$ & $\begin{array}{l}\text { ポータブル簡易全窒素・全りん計 } \mathrm{TNP}-10 \\
\text { 亜鉛還元一ナフチルエチレンジアミン吸光 } \\
\text { 光度法 }\end{array}$ \\
\hline $\begin{array}{l}\text { アンモニア態窒素 } \\
\left(\mathrm{NH}_{4}-\mathrm{N}\right)\end{array}$ & $\begin{array}{l}\text { ポータブル簡易全窒素・全りん計 } \mathrm{TNP}-10 \\
\text { インドフェノール青吸光光度法 }\end{array}$ \\
\hline 全窒素（T-N） & $\begin{array}{l}\text { ポータブル簡易全窒素・全りん計 TNP-10 } \\
\text { ペルオキソニ硫酸加熱分解一亜鉛還元ナフ } \\
\text { チルエチレンジアミン吸光光度法 }\end{array}$ \\
\hline 全リン（T-P） & $\begin{array}{l}\text { ポータブル簡易全窒素・全りん計 } \mathrm{TNP}-10 \\
\text { ペルオキソニ硫酸加熱分解—モリブデン青 } \\
\text { 吸光光度法 }\end{array}$ \\
\hline 化学的酸素要求量 $\left(\mathrm{COD}_{\mathrm{Cr}}\right)$ & 重クロム酸カリウム法 HACK, DR-2010 \\
\hline 生物学的酸素要求量(BOD) & ウィンクラーアジ化ナトリウム変法 \\
\hline 大腸菌群数 & Colilert-18/Quanti-Tray 法 \\
\hline 糞便性大腸菌群数 & Colilert-18/Quanti-Tray 法 \\
\hline
\end{tabular}

\section{3. 結果と考察}

\section{1 集落排水処理施設の水質調査結果の概要}

表 3 と表 4 に, 集落排水処理施設の水質試験結果を 示す、エジプト国における排水基準量も付記した。

(1) 水温, $\mathrm{pH}$

水温は $25.4^{\circ} \mathrm{C} \sim 26.2^{\circ} \mathrm{C}$ とっており, 安定している. 排水基準となる $35^{\circ} \mathrm{C}$ 以下は，十分に満足している.

図 5 に, $\mathrm{pH}$ の各槽水質試験結果を示す. 着色部は, 文献 ${ }^{10)}$ に示される日本での維持管理上の目安值（例） とされている範囲である。 2 回の測定時において若干 の違いはあるものの, 沈殿分離槽ではやや低い值を示 し, ばっ気槽において流入水よりも高くなる傾向は類 似していた，本施設の $\mathrm{pH}$ は，文献 ${ }^{10)} に$ 示される日本 の集落排水処理施設の傾向と概ね一致する. また, 2 回ともエジプト国の排水基準となる $\mathrm{pH} 6$ ～9 の範囲 となっている. 
表 3 水質試験結果（2015年10月27日）

\begin{tabular}{|c|c|c|c|c|c|c|c|c|c|}
\hline 項 目 & 単 位 & 原 水 & 沈分 1 & 沈分 2 & ばっ気 1 & ばっ気 2 & 沈 殿 & 消 毒 & 排水基準 \\
\hline 採水時間 & 時 分 & $12: 25$ & $12: 35$ & $12: 42$ & $12: 50$ & $12: 59$ & $1: 20$ & $1: 35$ & - \\
\hline 色 & - & 黒褐色 & 濁灰色 & 濁灰色 & 濁灰色 & 濁圧色 & 薄灰色 & 薄灰色 & - \\
\hline 水温 & ${ }^{\circ} \mathrm{C}$ & 26.0 & 25.8 & 26.0 & 26.2 & 25.9 & 26.0 & 26.3 & $35^{\circ} \mathrm{C}$ 以下 \\
\hline $\mathrm{pH}$ & - & 6.82 & 6.52 & 6.56 & 6.83 & 7. 32 & 7. 24 & - & $6 \sim 9$ \\
\hline 濁度 & NTU & 623.0 & 241.5 & 204.0 & 445.1 & 624.0 & 140.9 & 119.4 & - \\
\hline DO & $\mathrm{mg} / \mathrm{L}$ & 0.93 & 0.25 & 0.41 & 1.02 & 5.28 & 3. 21 & 2.52 & - \\
\hline 残留塩素 & $\mathrm{mg} / \mathrm{L}$ & - & - & - & - & - & - & 3.5 & - \\
\hline $\mathrm{NO}_{2}$ & $\mathrm{mg} / \mathrm{L}$ & - & - & 0.50 & 0.56 & 0.49 & - & 0.06 & - \\
\hline $\mathrm{NO}_{3}$ & $\mathrm{mg} / \mathrm{L}$ & - & - & 0.64 & 0.80 & 0.85 & - & 0.64 & - \\
\hline $\mathrm{NH}_{4}$ & $\mathrm{mg} / \mathrm{L}$ & 5.34 & 4.00 & 4.65 & 5.30 & 5.92 & - & 5.11 & - \\
\hline $\mathrm{T}-\mathrm{N}$ & $\mathrm{mg} / \mathrm{L}$ & 7.60 & - & - & - & - & - & 6.51 & - \\
\hline $\mathrm{T}-\mathrm{P}$ & $\mathrm{mg} / \mathrm{L}$ & 5.57 & - & - & - & - & - & 3. 20 & - \\
\hline $\mathrm{COD}_{\mathrm{Cr}}$ & $\mathrm{mg} / \mathrm{L}$ & 408 & - & 242 & - & 38 & - & 60 & 80 \\
\hline $\mathrm{BOD}$ & $\mathrm{mg} / \mathrm{L}$ & 380 & 322 & 306 & 176 & 60 & - & 5 & 60 \\
\hline 大腸菌群数 & $\begin{array}{c}\mathrm{MPN} \\
/ 100 \mathrm{~mL}\end{array}$ & $18.9 \times 10^{6}$ & - & - & - & - & - & 100以下 & $\begin{array}{c}\leqq 5000 \mathrm{CFU} \\
/ 100 \mathrm{~mL}\end{array}$ \\
\hline $\begin{array}{l}\text { 粪便性 } \\
\text { 大腸菌群数 }\end{array}$ & $\begin{array}{c}\mathrm{MPN} \\
/ 100 \mathrm{~mL}\end{array}$ & $17.5 \times 10^{4}$ & - & - & - & - & - & 100以下 & - \\
\hline
\end{tabular}

表 4 水質試験結果（2015年11月 3 日）

\begin{tabular}{|c|c|c|c|c|c|c|c|c|c|}
\hline 項 目 & 単 位 & 原 水 & 沈分 1 & 沈分 2 & ばっ気 1 & ばっ気 2 & 沈 殿 & 消 毒 & 排水基準 \\
\hline 採水時間 & 時分 & $13: 45$ & $13: 52$ & $14: 02$ & $14: 11$ & $14: 19$ & $14: 25$ & $14: 45$ & - \\
\hline 色 & - & 黒褐色 & 濁灰色 & 濁灰色 & 濁灰色 & 濁灰色 & 薄灰色 & 薄灰色 & - \\
\hline 水温 & ${ }^{\circ} \mathrm{C}$ & 25.9 & 25.8 & 26.1 & 25.8 & 25.6 & 25.0 & 25.4 & $35^{\circ} \mathrm{C}$ 以下 \\
\hline $\mathrm{pH}$ & - & 7.53 & 7.00 & 6.95 & 7.38 & 7.68 & 7.44 & - & $6 \sim 9$ \\
\hline 濁度 & NTU & 764.7 & 384.6 & 116.2 & 340.1 & 383.1 & 151.8 & 131.6 & - \\
\hline$\overline{\mathrm{DO}}$ & $\mathrm{mg} / \mathrm{L}$ & 1.99 & 1.61 & 1.25 & 1.29 & 4.12 & 2.24 & 3.40 & - \\
\hline 残留塩素 & $\mathrm{mg} / \mathrm{L}$ & - & - & - & - & - & - & 1.56 & - \\
\hline $\mathrm{NO}_{2}$ & $\mathrm{mg} / \mathrm{L}$ & - & - & 0.28 & 0.24 & 0.55 & - & 0.05 & - \\
\hline $\mathrm{NO}_{3}$ & $\mathrm{mg} / \mathrm{L}$ & - & - & 2.15 & 1.64 & 3. 30 & - & 1.21 & - \\
\hline $\mathrm{NH}_{4}$ & $\mathrm{mg} / \mathrm{L}$ & 2.31 & 2.54 & 3.79 & 5.67 & 5.75 & - & 5.04 & - \\
\hline $\mathrm{T}-\mathrm{N}$ & $\mathrm{mg} / \mathrm{L}$ & 7.30 & - & - & - & - & - & 7.10 & - \\
\hline $\mathrm{T}-\mathrm{P}$ & $\mathrm{mg} / \mathrm{L}$ & 6.02 & - & - & - & - & - & 4.36 & - \\
\hline $\mathrm{COD}_{\mathrm{Cr}}$ & $\mathrm{mg} / \mathrm{L}$ & 388 & - & 220 & - & 58 & - & 70 & 80 \\
\hline $\mathrm{BOD}$ & $\mathrm{mg} / \mathrm{L}$ & 360 & 309 & 266 & 128 & 80 & - & 43 & 60 \\
\hline 大腸菌群数 & $\begin{array}{c}\text { MPN } \\
/ 100 \mathrm{~mL}\end{array}$ & 11. $0 \times 10^{6}$ & - & - & - & - & - & 4,130 & $\begin{array}{c}\leqq 5000 \mathrm{CFU} \\
\quad / 100 \mathrm{~mL}\end{array}$ \\
\hline $\begin{array}{l}\text { 粪便性 } \\
\text { 大腸菌群数 }\end{array}$ & $\begin{array}{c}\text { MPN } \\
/ 100 \mathrm{~mL}\end{array}$ & $7.5 \times 10^{5}$ & - & - & - & - & - & 730 & - \\
\hline
\end{tabular}




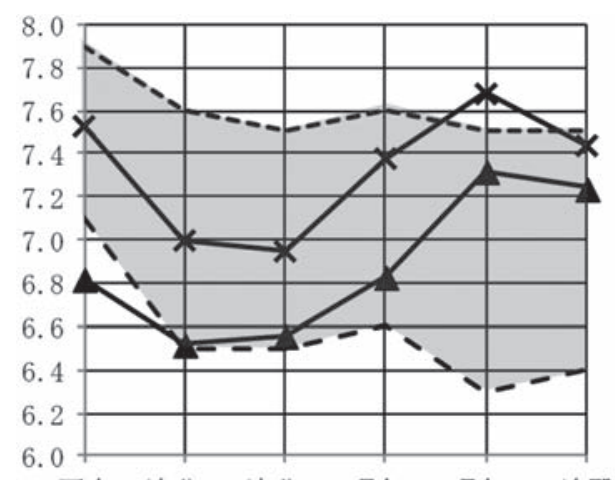

原水 沈分 1 沈分 2 曝気 1 曝気 2 沈殿

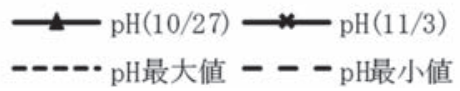

*最大值, 最小值は, 参考文献 ${ }^{10)}$ に示される通常運転 時の目安值

図 5 水質試験結果 $(\mathrm{pH})$

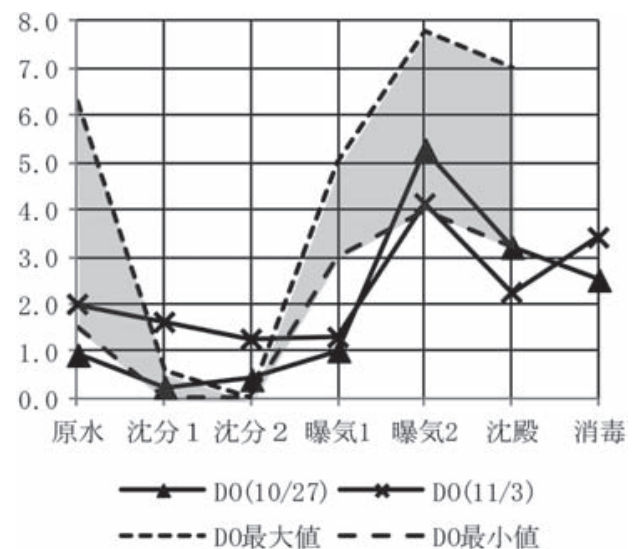

*最大值, 最小值は, 参考文献 ${ }^{10)}$ に示される通常運転 時の目安值

図 6 水質試験結果（DO）

\section{(2) DO}

図6に, DO の水質試験結果及び日本における目安 值 ${ }^{10)}$ を示す. 流入水の DO は日本の流入水水質と比較 すれば, $0.93 \mathrm{mg} / \mathrm{L}, 1.99 \mathrm{mg} / \mathrm{L}$ と低い数值となってい る。しかしながら，DOの挙動は日本の目安值に類似 した傾向を示した。すなわち, 沈殿分離槽で嫌気化さ れ, $0.25 \mathrm{mg} / \mathrm{L} \sim 1.6 \mathrm{mg} / \mathrm{L}$ まで減少し, その後, ばっ 気により DO が上昇し, 沈殿槽, 放流水にて若干小さ くなる傾向は, 本施設と日本の一般的施設と同一であ る。また、ばっ気槽第 1 室における DOが $1.02 \mathrm{mg} /$ $\mathrm{L}, 1.29 \mathrm{mg} / \mathrm{L}$ と低いものの, 第 2 室においては 5.28

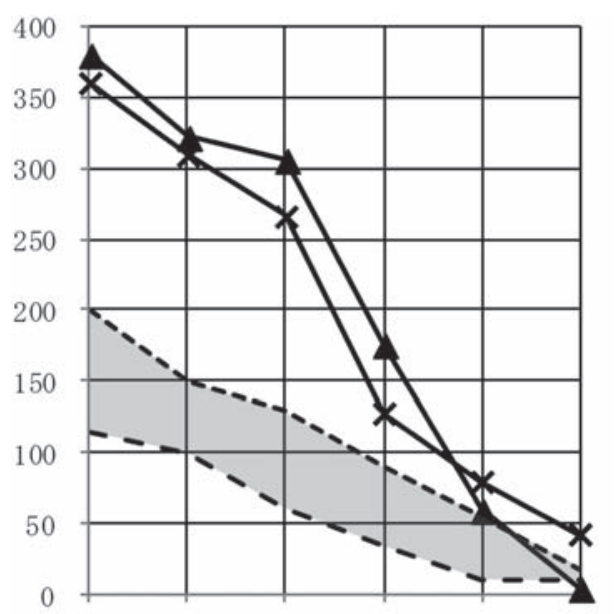

原水 沈分 1 沈分 2 曝気 1 曝気 2 消毒

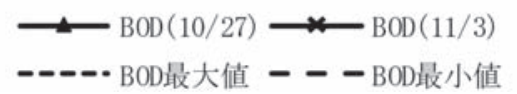

*最大值, 最小值は, 参考文献 ${ }^{10)} に$ 示される通常運転 時の目安值

図 7 水質試験結果 (BOD)

$\mathrm{mg} / \mathrm{L}, \quad 4.12 \mathrm{mg} / \mathrm{L}$ と高くなっており, $4.0 \mathrm{mg} / \mathrm{L}$ 以上が 確保されていることから, 良好なばっ気が行われてい ると判断できる.

(3) BOD

図 7 に, BOD の水質試験結果及び日本の目安值を 示した. 日本の流入 BOD は, $115 \sim 200 \mathrm{mg} / \mathrm{L}$ となっ て扔り, 本報告に扔ける処理施設の流入水質 $(360 \mathrm{mg} /$ $\mathrm{L}, 380 \mathrm{mg} / \mathrm{L})$ と大きく異なる. 本施設の BOD 負荷 の方が高いものの施設構造は, BOD 負荷にて決定し ていることから, 処理性能を確保できたと判断してい る.また, BODの除去プロセスは類似し, 各槽にお いて段階的に除去され, 各処理段階における BOD 除 去率は, 日本の目安值と同等の結果を得ることができ た. 10 月 27 日の試験結果において, 流入水 $380 \mathrm{mg} / \mathrm{L}$, 放流水 $5 \mathrm{mg} / \mathrm{L}, 11$ 月 3 日の試験結果において, 流入 水 $360 \mathrm{mg} / \mathrm{L}$, 放流水 $43 \mathrm{mg} / \mathrm{L}$ となっており, それぞれ の除去率，99\%，88\%と高い数值が得られた。いずれ の放流水の $\mathrm{BOD}$ もエジプト国の排水基準となる $60 \mathrm{mg} /$ Lを下回った。 BOD が11月 3 日の除去率となった場 合には，計画放流水量 $35 \mathrm{~m}^{3} /$ 日であることから，（360 $\mathrm{mg} / \mathrm{L}-43 \mathrm{mg} / \mathrm{L}) \times 35,000 \times 10^{-6}=11 \mathrm{~kg} /$ 日の $\mathrm{BOD}$ の污 濁負荷が軽減された結果となる. 放流する排水路の流 量は, $1.0 \mathrm{~m}$ 3/s であるため, パイロット施設である本 
施設による排水路の BOD 改善効果は, $0.1 \mathrm{mg} / \mathrm{L}$ 程度 である. 別途実施した排水路の水質試験結果から, 排 水路の BOD は, 12 30 mg/L となって㧍り，集落排 水処理施設設置による改善率は, $1 \%$ 以下となり, 低 いが，同様な施設がエジプト国内に広く普及すれば, その水質改善効果は大きいと期待される.

\section{(4) $\mathrm{COD}_{\mathrm{Cr}}$}

$\mathrm{COD}_{\mathrm{Cr}}$ は，10月27日の試験結果において，流入水の $408 \mathrm{mg} / \mathrm{L}$ から放流水では60 mg/L に大幅に低下した. また, 11月 3 日の試験結果においても流入水の $388 \mathrm{mg} /$ $\mathrm{L}$ から放流水は $70 \mathrm{mg} / \mathrm{L}$ となっており，10月と 11 月の $\mathrm{COD}_{\mathrm{Cr}}$ 除去率は，それぞれ $85 \%$ と $82 \%$ の良好な処理能 力が確認された。本施設の放流水の $\mathrm{COD}_{\mathrm{Cr}}$ は, いず れもエジプト国の排水基準となる $80 \mathrm{mg} / \mathrm{L}$ を達成して いる.

(5) $\mathrm{T}-\mathrm{N}, \quad \mathrm{T}-\mathrm{P}$

本施設では, $\mathrm{T}-\mathrm{N}$ と $\mathrm{T}-\mathrm{P}$ の処理性能は期待してい ない. しかしながら，10月27日と11月 3 日の試験結果 に扔いて, 流入水と放流水の $\mathrm{T}-\mathrm{N}$ を比較したところ, それぞれの除去率は $14 \%$ と $3 \%$ となった。 また，それ ぞれの T-P の除去率は，10月27日と11月 3 日の試験 結果において，それぞれ $43 \%$ と $28 \%$ となり，約30\%の 除去が期待できることがわかった。

\section{（6）濁度}

濁度は, 10月27日の試験結果において, 流入水 623.0 NTU, 放流水119.4 NTU であった. 11月 3 日の結果

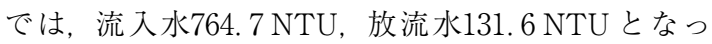
た. 10月と11月における除去率は，それぞれ $81 \%$ そ $83 \%$ であり，良好な結果が得られた。

\section{(7)残留塩素}

残留塩素は，それぞれ $3.5 \mathrm{mg} / \mathrm{L}, 1.56 \mathrm{mg} / \mathrm{L}$ となっ ている. 第 1 回目の水質試験結果を受けて, 注入量が 多いと判断されたため, 調整を行ったが, 日本におい て残留塩素濃度の目安とされている0.2 1. $0 \mathrm{mg} / \mathrm{L} よ$ り高い数值となっている。消毒薬剤費の節減のために も再度の調整が必要である。

\section{(8) 大腸菌群数}

10月27日時点において, 大腸菌群数と粪便性大腸菌 群数は, いずれも $100 \mathrm{MPN} / 100 \mathrm{~mL}$ 以下となった. 十分な消毒効果が得られている。また，11月 3 日にお いても, 大腸菌群数は, 流入水の $11,000,000 \mathrm{MPN} /$ $100 \mathrm{~mL}$ から放流水では4, $130 \mathrm{MPN} / 100 \mathrm{~mL}$ となり, 99. 9\%の除去率と高い消毒効果が得られた。 また, 粪
便性大腸菌群数も750, 000 MPN/100 mL が730 MPN/ $100 \mathrm{~mL}$ まで減少し, $99.4 \%$ の除去率が得られた.

エジプト国の大腸菌群数の排水基準は, $5,000 \mathrm{CFU} /$ $100 \mathrm{~mL}$ である. 日本の合併浄化槽の大腸菌群数 $(\mathrm{MPN} / 100 \mathrm{~mL})$ と粪便性大腸菌群数 $(\mathrm{CFU} / 100 \mathrm{~mL})$

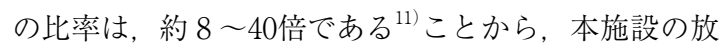
流水は, $91 \mathrm{CFU} / 100 \mathrm{~mL}(730 \mathrm{MPN} / 100 \mathrm{~mL})$ であり, この基準を満たしていると推察される.

\section{2 維持管理コスト}

日常管理は, スクリーンの清掃, バルブ操作及び停 電復帰時のブロワー電源のスイッチ操作である. バル ブ操作によって, 沈殿污泥の污泥濃縮眝留槽への移送 及びスカムの沈殿分離槽への移送が行われる. 日常管 理は，農民により組織された維持管理組合により実施 されている. 日常管理の方法は, アラビア語で写真の 解説と共に作成し, 維持管理担当者に指導した。煩雑 な操作はないため, 現在平常に運転されている。

定期点検は，エジプト国政府住宅省の下部組織とな る上下水道公社 (Holding company of water and wastewater）により実施されており，污泥引抜きと 搬出, 主要機器の維持管理, 重大故障時の対応が行わ れる。

水質試験は, 2.4 項に示した排水局の水質試験室に より 1 回/月行われ, 継続的に良好な放流水質の確認 を行う計画となっている.

維持管理費の内訳は, 表 5 に示すように, 年間 $\$ 1,488$ であり，これを全世帯の69軒から下水道料金として徵 収すれば, 年間 $\$ 21 /$ 世帯（\$1.8/月世帯）となる。こ

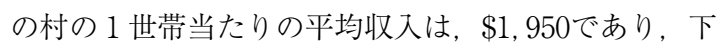
水道料金は収入の $1 \%$ 程度となり, 十分に支払い可能

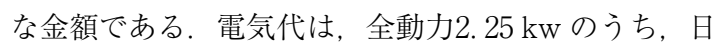
中 8 時間は, $1.5 \mathrm{kw}$ を太陽光発電によって賄えるこ とができるため，買電量を $22 \%$ 縮減できる，また，エ ジプト国は, 施策によって自然エネルギーの売電単価

\section{表 5 年間維持管理費内訳}

\begin{tabular}{l|c}
\hline \multicolumn{1}{c|}{ 項 目 } & 維持管理費 $(\$)$ \\
\hline 電気代 & 883 \\
\hline 消毒薬剤費 & 50 \\
\hline 人件費 & 305 \\
\hline 消耗品費 & 250 \\
\hline 污泥処理費 & 0 \\
\hline 合 計 & 1,488 \\
\hline
\end{tabular}


を買電単価の約 2 倍にしている. したがって, 太陽光 を売電とした場合には, 約50\%の電気代が縮減可能で ある.人件費は, 農民の代表に日常点検の対価として

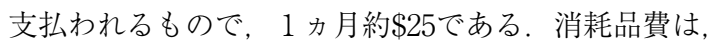
ブロワーフィルター交換, オイル代, 維持補修費を含 んで抢り，年間約 $\$ 250$ と見積もられる。な挹，污泥処 理費は上下水道公社が $1 \mathrm{~m}^{3}$ 当たり約 $\$ 2$ で買い取るこ ととなっているが、污泥の収集は, 国の施策で確実で あるものの単価については, 変動することも考えられ ることから, 表 5 では無償引き取りとして維持管理費 を見積もった。 また, 施設の更新費は, 集落排水処理 施設の平均耐用年数を 30 年とすれば, 年間 $\$ 2,533$ とな り，1世帯当たり年間 $\$ 36$ の負担である。これを加算 しても支払い可能な維持管理費となる.

今回の実験施設の設置によって, 建設費と維持管理 費の安価な農村向けの集落排水処理施設の効果が確認 できた，本施設の日常管理は容易であり，高度な維持 管理知識も必要としないことから, 農民の自主管理と しても短時間の指導にて対応可能であることも実証さ れた. 今後, 農村部での下水道整備率を高めるために, 安価で維持管理の容易な同型式の施設がエジプト国の 全国各地の農村部に設置されることが望まれる。本施 設は, 水質污染が課題となっているその他新興国へ展 開も十分可能であると判断される.

\section{4.まとめ}

エジプト国デルタに集落排水処理施設を初めて設置 し, 運転を行った. 2 回の調査結果の概要を以下にま とめる.

（1）濁度は，流入水の623. 0 NTU と764.7 NTU が，施 設の放流水では，それぞれ119.4 NTU と131. 6 NTU に大幅に低減され，その除去率は $80 \%$ に達した。

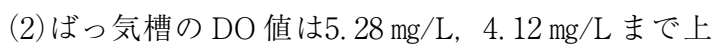
昇して日本国内に打ける運転管理の目安としている $4.0 \mathrm{mg} / \mathrm{L}$ 以上に確保され, 好気条件が良好に維持さ れていると判断できる.

(3)BOD は, 流入水の $380 \mathrm{mg} / \mathrm{L}$ と $360 \mathrm{mg} / \mathrm{L}$ から放流 水では $5 \mathrm{mg} / \mathrm{L}$ と $43 \mathrm{mg} / \mathrm{L}$ となっており, それぞれの除 去率は $99 \%$ と $88 \%$ と極めて高かった。いずれもエジプ 卜国の排水基準となる $60 \mathrm{mg} / \mathrm{L}$ を下回った。
(4) $\mathrm{COD}_{\mathrm{Cr}}$ は, 流入水の $408 \mathrm{mg} / \mathrm{L}$ と $388 \mathrm{mg} / \mathrm{L}$ から放流

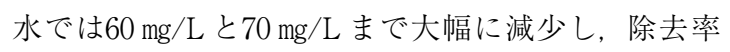
はそれぞれ $85 \%$ と $82 \%$ となった。これらの放流水の $\mathrm{COD}_{\mathrm{cr}}$ は，エジプト国の排水基準となる $80 \mathrm{mg} / \mathrm{L}$ を満 足している.

(5) 大腸菌群数と霬便性大腸菌群数は, それぞれ除去 率99.9\%と99.4\%の除去率が得られた。本施設は，下 水道が未整備となっている農村部流域において, 公衆 衛生の著しい向上に寄与できる.

(6) 建設費, 維持管理費共に大幅なコス卜縮減を達成 し, 農村向け集落排水処理施設として全国展開可能と 判断できる。

\section{参考文献}

1) National Water Resources Plan 2017; Ministry of Water Resources and Irrigation, p. 2-34, 2005.

2 ）(独)国際協力機構（JICA）; エジプト・アラブ共和国 ナイルデル夕地域農業用水水質改善・再利用計画プ ロジェクト準備調查報告書, p. 9-21，2011.

3 ）小木曽凡芳, 大石貴行, 鈴木祥広 ; マイクロバブル によるナイルデルタの農業用水の浄化, 環境技術, 44, (4), p.36-43, 2015.

4) Ministry of Water Resource and Irrigation National Water Research Center Drainage Research Institute; Drainage Water Status in the Nile Delta Year Book 2008-2009 Technical Report No. 79, June 2010.

5 ）北村浩二 ; エジプトにおける灌湛のための排水再利 用の現状と課題, 水土の知, 80, (2), p.115-118, 2012.

6) The Center for Environment and Development for the Arab Region and Europe (CEDARE); Egypt Water Sector M\&E Rapid Assessment Report, 2014.

7 ）上村繁樹，大久保努，多川正，荒木信夫，原田秀樹 ; エジプトに扔ける下水放流水の灌溉利用の実態とそ の改善に向けての今後の展望, 用水と廃水, $57,(3)$, p.219-229, 2015.

8 ) 進藤惣治, 山本公一; 地域の合意形成に基づく水質 保全・排水再利用の取組み, 水土の知, 83, (7), p. 557 $-560,2015$.

9) Set of Laws and Decrees on Protection of the river Nile against pollution \& drainage of liquid wastes, The middle east library for economic services, p.51-56, 2009.

10）(社)地域資源循環技術センター; 農業集落排水処理 施設維持管理マニュアル $\quad$ 日本農業集落排水協会一 I 型編 (JARUS I 型) , p.92-95, 2010.

11）増田純雄, 山内正仁, 渡邊創太, 倉山信博, 土手裕, 丸山俊朗; 都市排水路の大腸菌群污染に関する調 查·研究, 環境工学研究論文集, 40, p.523-530, 2003. 